\title{
APPLYING THE INTERNATIONAL ESCO CONCEPT TO ENERGY SAVING PROJECTS IN THE ENERGY PRODUCTION SECTOR IN NORTHWEST RUSSIA
}

\author{
Hannariina Honkanen \\ Lappeenranta University of Technology, Finland
}

\begin{abstract}
The economy of the Russian Federation and its growth rate currently depend greatly on the country's fuel and energy industry and actual development of the business. To maintain the energy production at least at the present level, capacity must be increased by several gigawatts annually. This sets up an extensive need for investments. One effective solution to the problem is the realization of energy saving investments, which have very high potential in Russia.
\end{abstract}

The EU project FRESCO (10/2003-12/2005), administered by Lappeenranta University of Technology, studies the possibilities to promote Finnish energy business in Northwest Russia. The project examines the ESCO concept that is proposed and anticipated to be a potential finance tool in energy saving projects in the target area. The international ESCO business aims at finding solutions to the following problems: the lack of investments, undeveloped technology in use, ineffective energy systems, bureaucracy and risks.

Potential and feasible ESCO project targets in energy production include a new pre-furnace for utilization of bio fuels, a new economizer and a boiler automation upgrade. In the near future - when markets exist - the ESCO concept could also be a finance tool in utilizing waste in energy production. For example bio waste from sawmills has significant potential as fuel for local boilers.

Through energy efficiency projects, greenhouse gas emissions can also be reduced. The international climate policy brings in its own possibilities to finance energy investments and climate projects. Russia ratified the Kyoto Protocol in February 2005 and can therefore take part in international emissions trading in 2008 if the country observes the provisions of the Protocol concerning emission reduction units. Alternatives for carbon finance options could be, in addition to international emissions trading, Joint Implementation projects and GIS projects, in which so called "hot air" is utilized.

\section{KEYWORDS}

Energy service company; ESCO concept; Energy saving project; Energy production; Northwest Russia 


\section{INTRODUCTION}

The economy of the Russian Federation and its growth rate currently depend greatly on the country's fuel and energy industry and actual development of the business. To maintain the energy production at least at the present level, capacity must be increased by several gigawatts annually. This sets up an extensive need for investments. One effective solution to the problem is the realization of energy saving investments, which have very high potential in Russia [8]. An on-going steady increase in energy tariffs and possible World Trade Organization accession will create good incentives for Russian companies and municipalities to save more energy [4].

The EU project FRESCO (10/2003-12/2005), administered by Lappeenranta University of Technology, studies the possibilities to promote Finnish energy business in Northwest Russia (NWR). The project examines the ESCO (Energy Service Company) concept that is proposed and anticipated to be a potential finance tool in energy saving projects in the target area, especially in the area of St. Petersburg and in the Leningrad oblast. The targets of the project are:

- Studying the possibilities and potential of ESCO business in NWR';

- Building the contact network for Finnish energy sector companies in NWR;

- A co-operation strategy for the promotion of clean energy source utilization and Finnish technology export to NWR; and

- To build the model for ESCO business in NWR for Finnish companies.

With regard to the international ESCO business, the aim of the FRESCO project is at finding solutions to the following problems in energy business in Northwest Russia: the lack of investments, undeveloped technology in use, ineffective energy systems, bureaucracy and risks. An ESCO service is one possible tool for implementing energy saving measures reported in energy audit reports [6].

\section{ESCO CONCEPT}

ESCO activity, also known as energy performance contracting (EPC), means that an external organization (ESCO) implements a project to deliver energy efficiency, or a renewable energy project, and uses the stream of income from the cost savings, or the renewable energy produced, to repay the costs of the project, including the costs of the investment (see Figure 1) [2]. In this way the client does not need to tie its own resources - capital or staff - to the investment.

ESCOs are seen as an important vehicle for promoting energy efficiency around the world, especially in countries experiencing increased competition and privatization in the electric utility business $[5,10]$.

\footnotetext{
${ }^{1}$ All the publications of the project are public and are available on the project web site: http://www2.et.lut.fi/fresco/. In the project studies, Finnish and Russian energy expert knowledge has been utilized.
} 


\section{Idea of ESCO-service}

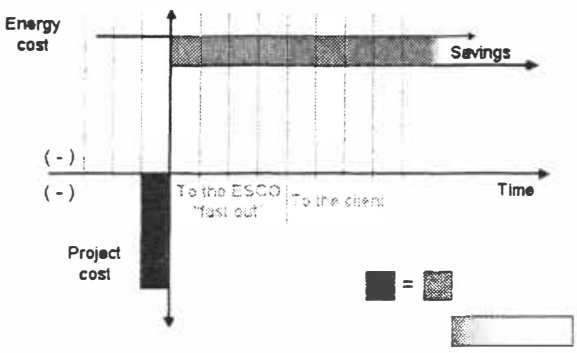

Figure 1. Principle of the ESCO concept [6].

\subsection{Energy Service Companies}

An ESCO company provides integrated energy services to its customers. The customer is usually a large energy user or utility. The ESCO company's activity may include implementing energy efficiency projects and also renewable energy projects, often on a turnkey basis [1].

ESCO companies guarantee energy savings, so they differ from any conventional companies offering energy related services. ESCO companies can also finance or via energy savings guarantee assistance in arranging financing for the operation of an energy system. The remuneration in ESCO projects is directly tied to the energy savings achieved [2].

The basic financial elements of ESCO projects are verification of the energy savings, investment costs and the client's payments to the ESCO [6]. There are two primary savings structures in ESCO project schemes: shared savings and guaranteed savings (see Figure 2). In the latter scheme the ESCO guarantees a certain level of energy savings and in this way shields the client from any performance risk. In the shared savings scheme the client assumes no financial risk, which is the reason why the shared savings concept is a good introductory model just in developing markets $[2,3]$.

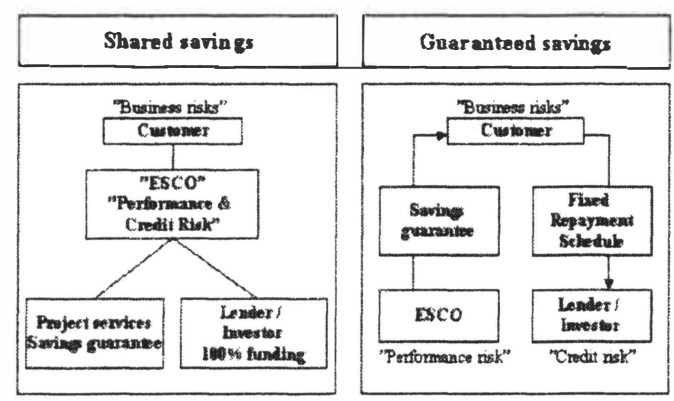

Figure 2. Two main savings structures in the ESCO concept. (Dreessen 2003) 
In general, the greater part of the ESCO activity is all about contracts. Other issues to be considered in the ESCO context are investment criteria, guarantees, insurances and transfer of ownership [6].

A typical ESCO project managed by an energy service company includes the following elements [1]:

- Investment grade energy audit;

- Identification of possible energy saving and efficiency improving actions;

- Comprehensive engineering and project design and specifications;

- Guarantee of the results by proper contact clauses;

- Code compliance verification and guarantee;

- Procurement and installation of equipment;

- Project management and commissioning;

- Facility and equipment operation and maintenance (O\&M) for the contract period;

- Purchase of fuel and electricity (e.g. to provide heat, comfort and light);

- Monitoring and verifications (M\&V) of the savings results; and

- Project financing.

In the Finnish MotivaESCO${ }^{2}$ concept there are only four basic elements: 1) Identification of the energy saving measures to be included in the contract, 2) arranging financing for the measures, 3) implementing the measures and 4) verification of the savings [6]. However, ESCO models in different countries differ from each other and all of the above-mentioned elements are not necessarily included in every ESCO project.

\subsection{ESCO's in Europe}

The original European ESCO concept was already applied in Europe more than 100 years ago. The concept moved to North America and has been practised there since the oil shocks of the 1970s, but it has been revived in Europe during past few years. The market potential for energy efficiency services in Western Europe is estimated to be high: 5-10 billion euros per annum. The market of these services was estimated to be 150 million euros per annum in $2000[1]$.

The current status of the European ESCO industry shows major differences from country to country. The range is from the "top countries" (Germany, Austria, the UK, Spain, Hungary) to middle range countries (Sweden, France, the Czech Republic, Italy) and other countries, which have been falling behind with their ESCO industry development [2].

To foster the development of the ESCO industry in Europe, Bertoldi [2] points out the need for the following actions in European countries:

- Increase dissemination of ESCO services and projects;

- Launch an accreditation system for ESCOs (to provide a qualified and reliable service);

- Develop financing sources;

- Standardize contracts and M\&V;

- Ensure that governments take the lead with measures in public buildings; and

- Develop a Europe-wide third party financing? (TPF) network.

\footnotetext{
${ }^{2}$ Motiva is a govemment-owned company pioneering in the ESCO activity in Finland.

${ }^{3}$ Third party financing refers simply to debt financing.
} 
Table 1. Technical differences in heat production between Eastern and Western Europe. [7].

\begin{tabular}{|c|c|c|}
\hline & Eastem Europe & Western Europe \\
\hline Characteristics & $\begin{array}{l}\text { Combined heat production } \\
\text { (CHP) and heat only } \\
\text { boilers (HOB) utilized } \\
\text { - Undeveloped automation } \\
\text { and control systems }\end{array}$ & $\begin{array}{l}\text { - } \text { CHPs and HOBs utilized } \\
\text { - CHP share varies according to } \\
\text { market conditions } \\
\text { - Online monitoring and control } \\
\text { systems used in larger district } \\
\text { heating systems }\end{array}$ \\
\hline Main problems & $\begin{array}{l}\text { - Low efficiencies } \\
\text { - High emissions } \\
\text { - Often low share of } \mathrm{CHP} \\
\text { production }\end{array}$ & $\begin{array}{l}\text { Further increases of CHP would } \\
\text { improve efficiency } \\
\text { - Lower emissions but further need to } \\
\text { reduce }\end{array}$ \\
\hline
\end{tabular}

\section{ENERGY PRODUCTION SECTOR IN NORTHWEST RUSSIA}

The major technical differences between Eastern European, such as Russian, and Western district heating systems are in the technical configurations, performance and efficiency. Technical differences in heat production are seen in Table l. However, the trend in many Eastern European countries is to rapidly modernize their systems in line with Westem standards [7].

The heat production plants in Russia use fossil fuels widely. The following fuels are used: natural gas, town gas, heavy fuel oil $^{4}$, coal, lignite and in some cases biomass. Also light heating oil may be used. One of the foreseen energy production technology trends in Russia is that boiler plants using heavy fuel oil or coal as fuel are renovated to use either bio fuel or natural gas in order to save energy and minimize emissions. Other focal energy production trends are [7]:

- Energy audits carried out on all boiler plants;

- Boilers equipped with modern automation systems; and

- Unmanned operation.

The Russian energy system is composed of four levels: the federal level, federal or regional administration level, regional level and corporate level (see Figure 3). The ESCO business is carried out at the grass root level of the management scheme. The realizers are the energy consumers of energosí and district heating companies [7].

\footnotetext{
${ }^{4}$ Heavy fuel oil is known also as 'mazut'.

5 "Energos" refers to "AO energos" which are local energy companies attached to RAO UES Russia.
} 


\begin{tabular}{|c|c|}
\hline \multicolumn{2}{|c|}{ Federal Level } \\
\hline 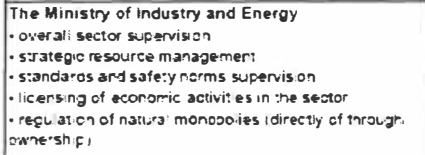 & 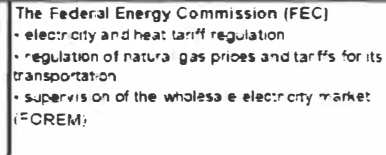 \\
\hline \multicolumn{2}{|c|}{ FederallRegionaladministrationlevel } \\
\hline \multicolumn{2}{|l|}{ 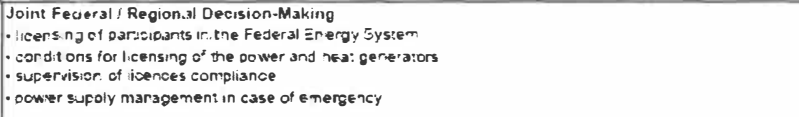 } \\
\hline \multicolumn{2}{|c|}{ Regional Level } \\
\hline $\begin{array}{l}\text { Regional Administrations } \\
\text { - superv sion of actidities odtside the Fejeral Enerzy } \\
\text { Sy'stem } \\
\text { - licensirig of energy sector cor sivetion assignmen: of } \\
\text { bu loing olors of iano } \\
\text { - preven:ion of oclutior. ervironmen:al management }\end{array}$ & 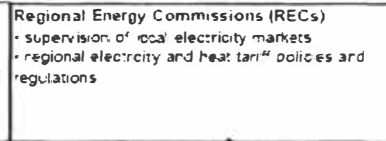 \\
\hline \multicolumn{2}{|c|}{ Corporatelevel } \\
\hline 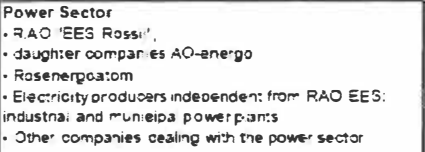 & $\begin{array}{l}\text { Fuel Sector } \\
\text { - Gazprom } \\
\text { - Rosugol } \\
\text { - Rosineft } \\
\text { - Cther companies dealing win the fue industry }\end{array}$ \\
\hline
\end{tabular}

Figure 3. Management scheme of the Russian power sectorí [7].

\section{ENERGY SAVING PROJECTS}

The ESCO model, as energy saving activities on the whole, is a rather new matter for Russia. Several ESCO pilot projects have been implemented, and these projects were mostly initiated with the assistance of foreign organizations and financial institutions. Only a small number of local ESCO companies operate in Russia [4].

The most attractive investment projects for ESCO activities are short and medium-term energy efficient projects. The payback time should not be longer than 6-7 years. The main ESCO project criteria defining the investments are as follows [7]:

- Payback period; and

- Investment volume and effect of the project implementation.

Energy tariffs have been rather low in Russia, which consequently means that energy saving projects are not attractive as such. There have to be other further arguments, such as deferred investments, to make the measures feasible [7]. However, the electricity, heat and gas tariffs are steadily increasing, which can change the situation in the near future.

\footnotetext{
${ }^{6}$ The scheme is dated back to the year 2004 and there have already been some changes since in energy sector.
} 


\subsection{Technical applications}

Energy services could include a variety of activities, such as energy analysis and audits, energy management, project design and implementation, maintenance and operation, monitoring and evaluation of savings, property management, and energy and equipment supply [2].

The following applications can be taken into consideration when seeking investment project targets for energy efficiency in heat production in NWR [7]:

- Reconstruction of heavy fuel oil storage, preheating pumping and recirculation system;

- New burniers with automation of burning process;

- Insulation and air-tightening of boiler casing;

- New automatic steam pressure reduction valves;

- New condense separators installed to heat exchangers; and

- Frequency converters for electric motors of main pumps, air ventilators and flue gas fans.

The most potential and feasible ESCO project targets in energy production include a new prefurnace for utilization of bio fuels, a new economizer and a boiler automation upgrade [7].

One case-study in FRESCO project reports is "Introduction of biomass boilers in the Brovlyany-Lesnoy Boiler House". The source of information is the World Bank and GEF (Global Environment Facility). One of the boilers (new boiler, $5 \mathrm{MW}$ ) has the following fuel supply sources: saw dust $8 \%$, wood chips $32 \%$ and other wood-based fuel $60 \%$. The investigation shows that the annual fuel cost is $39 \%$ lower when using biomass than when using natural gas. However, the conclusion is that investing in bio fuel boilers is strongly dependent on the fuel price [7].

\subsection{Carbon finance in energy saving projects}

Through energy efficiency projects, greenhouse gas emissions can also be reduced. The international climate policy brings its own possibilities to finance energy investments and climate projects. Russia ratified the Kyoto Protocol in February 2005 and can therefore take part in international emissions trading in 2008 if the country observes the provisions of the Protocol concerning emission reduction units.

The implementation of the Kyoto Protocol and its flexible mechanisms - ET (emission trading), CDM (clean development mechanism) and JI (joint implementation) - will create a new opportunity for developing the ESCO industry [2]. Alternatives for carbon finance options could also be GIS (Green Investment Scheme) projects, in which so-called "hot air", is utilizied [9].

An ESCO project may produce not only energy savings but also so-called "carbon assets" that can be e.g. emission reductions, emission allowances or green certificates. The carbon assets have monetary value and can be used for paying back the investment in parallel with energy savings [9].

\footnotetext{
7 "Hot air" refers to the surplus emitting allowances allocated to Russia under the Kyoto Protocol in 1997.
} 


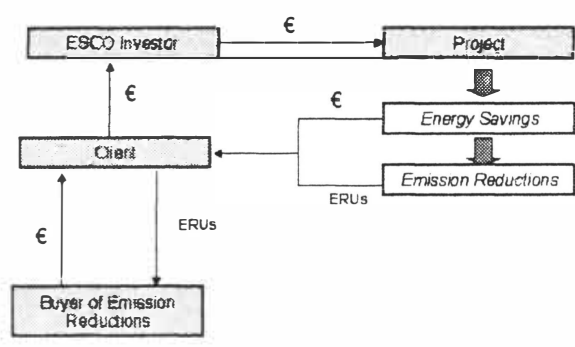

(a)

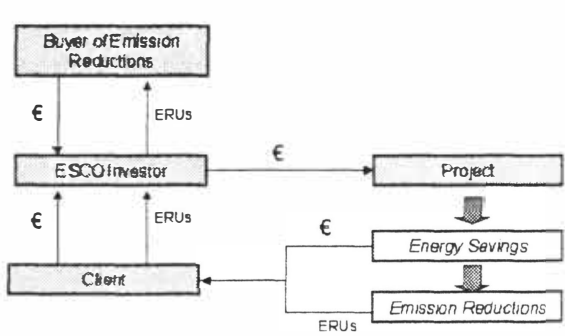

(b)

Figure 4. Two examples of the concept of ESCO and carbon finance [9].

Figure 4 presents two examples of integrating carbon finance into the ESCO model. In alternative (a) the client sells the emission reductions, and part of the revenues goes to the ESCO investor. In alternative (b) the ESCO company accepts emission reductions as a partial payment for the project.

In some cases, carbon finance can significantly improve the economic and financial fea sibility of an energy project. However, a bad project can seldom be turned into a good one with carbon finance. It can improve project feasibility in two ways [9]:

- It may increase the lendersi confidence in the project thus improving the debt-equity ratio and helping financial closing.

- The additional cash flow from the sale of the carbon asset improves the project's economic feasibility, shortens the payback time and increases the internal rate of return.

Biomass projects and methane capture are the project types which may have significant possibilities in using carbon financing as a part of the total financing. According to estimates presented in FRESCO studies, carbon finance can generally improve the rate of return of a project by $1-5$ percentage points [9].

\section{CONCLUSIONS}

In general, Russian heat production facilities have undeveloped automation and control systems. The main problems in the boiler-houses are low efficiencies and high emissions. The fossil fuels are widely used in Russian boiler plants.

The most attractive investment projects for ESCO activities are short and medium-term energy efficient projects. Russian energy tariffs are steadily increasing, which can make investments more feasible and thus bring new possibilities to energy saving project implementation.

Russia ratified the Kyoto Protocol in February 2005 and can therefore take part in international emissions trading in 2008 if the country observes the provisions of the Protocol concerning emission reduction units. Alternatives for carbon finance options could be, in 
addition to international emissions trading, Joint Implementation projects and GIS projects, in which so-called "hot air" is utilized.

Potential and feasible ESCO project targets in energy production include a new pre-furnace for utilization of bio fuels, a new economizer and a boiler automation upgrade. In the near future - when markets exist - the ESCO concept could also be a finance tool in utilizing waste in energy production. For example bio waste from sawmills has significant potential as fuel for local boilers, if it is a feasible option for fossil fuels.

\section{REFERENCES}

[1] Bertoldi, P., Berrutto, V., De Renzio, M., Adnot, J., Vine, E., 2003. How are ESCOs behaving and how to create a real ESCO market? In: Proceedings of the European Council for Energy Efficient Economy 2003 Summer Study. European Council for an Energy Efficient Economy, Stockholm.

[2] Bertoldi, P., Rezessy, S., Vine, E., 2005. Energy service companies in European countries: Current status and a strategy to foster their development. Energy Policy. Article in press [Retrieved October 11, 2005]

[3] Dreessen, T., 2003. Advantages and disadvantages of the two dominant world ESCO models; shared savings and guaranteed savings. In: Bertoldi P. (Ed.), Proceedings of the first PaniEuropean Conference on Energy Saving Companies.

[4] Efremov, D., Smirnyagin, D., Valerianova, O., Hernesniemi, H. 2004. ESCO companies in Northwest Russia - Legal issues and organizational schemes. [pdf document] ETLA, The Research Institute of the Finnish Economy, Helsinki. FRESCO project report. 46 p. Discussion papers Nro. 912. ISSN 0781-6847. [Retrieved October 10, 2005] From: http://www.etla.fi/files/996_Dp912.pdf

[5] Goldman, C., Dayton, D., 1996. Future prospects for ESCOs in a restructured electricity industry. Proceedings of the 1996 ACEEE Summer Study, American Council for an Energy-Efficient Economy. Vol 10, Washington, DC, pp. 59-69.

[6] Silvonen, S., 2004. Basics of ESCO and some cases. [pdf document] Motiva Ltd. Presentation in international ESCO seminar in St. Petersburg on May 2004. FRESCO project. [Retrieved October 12, 2005] From:

http://www.et.lut.fi/fresco/Presentation_Silvonen_12_05_04.pdf

[7] Olkinuora, J., 2004. Study: Applied technology in energy production, distribution and end-use, and future technological trends. [pdf document] Enprima Ltd. FRESCO project report. [Retrieved October 10, 2005] From: http://www.et.lut.fi/fresco/FRESCOreport_2.pdf

[8] Rokhlikov, I., Iljin, G., 2005. ESCO-energiapalveluyritysten perustaminen ja toiminta Pietarin alueella. FRESCO project report. Vantaan Energia Oy and Regional Economic Development Agency. The report is incomplete, not yet available in public. (In Finnish)

[9] Tynjälä, T., 2005. The Impact of the Carbon Finance on the Feasibility of ESCO Operations in Northwest Russia. [pdf document] GreenStream Network Oy. FRESCO project report. 84 s. TT-050228-1680. [Retrieved October 10, 2005] From: http://www.et.lut.fi/fresco/FRESCOreport_3.pdf

[10] Vine, E., Hamrin, J., Crossley, D., Maloney, M., Watt, G., 2003. Public policy analysis of energy efficiency and load management in changing electricity businesses. Energy Policy 31 (5), 405-430.

[11] Vine, E., 2005. International survey of energy service company (ESCO) industry. Energy Policy 33 (5), 691-704. 